ISSN : 2548-6985

\title{
E-Learning Pada Sekolah Menengah Kejuruan Swasta Pencawan Medan Program Studi Multimedia
}

\author{
1) Melisa Rahel \\ UNIKA ST. Thomas SU, JI. Setiabudi No 479 F Tanjungsari, Medan, Sumatera Utara, Indonesia \\ E-Mail: melisa.rahel@gmail.com \\ ${ }^{2)}$ Wasit Ginting \\ UNIKA ST. Thomas SU, Jl. Setiabudi No 479 F Tanjungsari, Medan, Sumatera Utara, Indonesia \\ E-Mail : aronbarusjahe@gmail.com
}

\begin{abstract}
ABSTRAK
Teknologi web memungkinkan perancangan sistem pembelajaran jarak jauh (e-learning) tanpa dibatasi oleh waktu, tempat maupun ruang. Perancangan sistem memanfaatkan alat-alat perancangan seperti diagram alir data, entity relationship diagram dan diaplikasikan menggunakan bahasa HTML, CSS, Javascript, PHP dan basisdata MySQL. E-learning yang dibangun pada SMK Pencawan Medan mendukung proses belajar siswa, mempermudah interaksi siswa dengan materi, diskusi antara siswa dengan guru maupun sesama siswa dalam forum diskusi, mengirim file tugas dan mengerjakan quis yang nantinya dapat dijadikan sebagai tolak ukur dalam mengukur sejauh mana tingkat pemahaman siswa terhadap suatu materi. Siswa dapat saling berbagi informasi dan dapat mengakses bahan-bahan belajar setiap saat dan berulang-ulang, dengan kondisi yang demikian siswa dapat lebih memantapkan penguasaannya terhadap materi pembelajaran.
\end{abstract}

\section{Kata Kunci: E-Learning, Diskusi, Forum, Quis, Absensi}

\section{PENDAHULUAN}

Keterbatasan waktu, tempat dan ruang menjadi kendala utama dalam peningkatan mutu dan kualitas pendidikan. Dalam permasalahan ini, menyampaikan informasi yang biasanya hanya melalui media cetak dirasakan kurang cukup, karena saat ini sudah banyak orang yang menggunakan internet sebagai media informasi. Penggunaan teknologi informasi, dalam hal ini internet dipercaya mampu meningkatkan mutu dan kualitas pendidikan. Salah satu upaya untuk meningkatkan mutu pendidikan yaitu dengan memanfaatkan teknologi informasi yaitu dengan menggunakan teknologi website dalam mendukung proses belajar mengajar di kelas, atau biasa dikenal dengan e-learning ${ }^{[1]}$.

Dengan melihat latar belakang di atas, perlu dirancang suatu website pembelajaran yang nantinya akan mendukung proses belajar siswa selain di sekolah, mempermudah interaksi siswa dengan materi, diskusi antara siswa dengan guru maupun sesama siswa dalam forum diskusi, mengirim file tugas dan mengerjakan kuis yang nantinya dapat dijadikan sebagai tolak ukur dalam mengukur sejauh mana tingkat pemahaman siswa terhadap suatu materi. Siswa dapat saling berbagi informasi dan dapat mengakses bahanbahan belajar setiap saat dan berulang-ulang, dengan kondisi yang demikian siswa dapat lebih memantapkan penguasaannya terhadap materi pembelajaran.
Berdasarkan latar belakang masalah yang telah diuraikan di atas, maka yang menjadi masalah dalam penelitian ini adalah Bagaimana merancang desain yang interaktif dan menarik untuk e-learning pada SMK Swasta Pencawan Medan, Bagaimana mengimplementasikan sistem pembelajaran interaktif untuk e-learning pada SMK Swasta Pencawan Medan dalam bentuk website?, Bagaimana menjadikan fitur quis sebagai tolak ukur dalam melihat sejauh mana tingkat pemahaman siswa terhadap suatu materi yang diberikan oleh guru?

Tujuan yang diharapkan dari penelitian ini adalah Siswa SMK Pencawan Program Studi Multimedia dapat belajar mandiri tanpa harus bertatap muka langsung dengan guru atau pengajar yang bersangkutan, Siswa SMK Pencawan Program Studi Multimedia mendapat materi pembelajaran yang tidak hanya bersumber dari buku tetapi juga dari berbagai sumber seperti video tutorial, e-book ataupun dari sumber-sumber lain yang berasal dari internet sehingga menghemat biaya pembelian buku sekolah.

Manfaat dari penelitian adalah Sistem pembelajaran bersifat fleksibel karena siswa SMK Pencawan Program Studi Multimedia dapat belajar dimana saja dan kapan saja, selama terhubung dengan internet, Menghemat biaya pendidikan (pembelian buku-buku sekolah, alat-alat tulis) dan biaya perjalanan menuju sekolah, Mendidik siswa SMK 
Pencawan Program Studi Multimedia menjadi lebih mandiri dalam proses belajar mengajar.

\section{METODOLOGI PENELITIAN}

Metodologi pengumpulan data dapat didefinisikan sebagai suatu cara yang digunakan untuk memperoleh data yang dibutuhkan sebagai bahan masukan bagi penulis dalam penyusunan tugas akhir adalah sebagai berikut:

\section{A. Penelitian Lapangan}

yaitu metode yang dilakukan langsung berhadapan dengan objek permasalahan dengan tujuan mengumpulkan data sebanyakbanyaknya untuk bahan pertimbangan dan pengambilan keputusan untuk tahap selanjutnya. Pengumpulan data ini meliputi:

1. Wawancara, yaitu teknik pengumpulan data dengan cara mengadakan tanya jawab secara langsung dengan narasumber yang terkait dengan permasalahan yang diambil untuk memperoleh data dan informasi.

2. Observasi, yaitu teknik pengumpulan data dengan cara melakukan pengamatan secara langsung terhadap objek permasalahan yang diambil.

\section{B. Penelitian Kepustakaan}

Penelitian ini sifatnya teoritis dengan cara memperoleh informasi dalam buku bacaan yang berhubungan dengan masalah yang akan dibahas yang berasal dari akademik maupun luar akademik.

1. Data Yang Dibutuhkan. Dalam menyelesaikan tugas akhir ini, penulis membutuhkan data yang berhubungan dengan sistem informasi ini. Dari hasil pengamatan sementara penulis membutuhkan data yang akan diproses sebagai berikut:

1. Data Primer, Yaitu data yang diperoleh langsung dari lapangan. Data yang berhubungan dengan E-Learning Pada SMK Swasta Pencawan Medan Program Studi Multimedia.

2. Data Sekunder, Merupakan data yang diperoleh langsung dari sumber dalam bentuk laporan yang didapat dari sumber studi perpustakaan yaitu ELearning Pada SMK Swasta Pencawan Medan Program Studi Multimedia yang bersifat teoritis.

2. Teknik Analisis Data

Analisis data dapat mendefinisikan dan mengevaluasi permasalahan dan hambatan yang mungkin dapat terjadi. Untuk memecahkan masalah dengan menggunakan suatu metode pemakaian komputer membutuhkan suatu sistem yang dibangun dan dirancang yaitu pengumpulan data, penggolongan dan menganalisisnya.

Sistem adalah suatu jaringan kerja dari prosedur-prosedur yang saling berhubungan, berkumpul bersama-sama untuk melakukan suatu kegiatan atau untuk menyelesaikan suatu sasaran tertentu ${ }^{[3]}$.

Sistem adalah sekumpulan komponen yang saling berhubungan dan bekerja sama untuk mencapai suatu tujuan ${ }^{[8]}$.

Informasi adalah data yang diolah menjadi bentuk yang lebih berguna dan lebih berarti bagi yang menerimany ${ }^{[3]}$.

Informasi adalah data yang telah diklasifikasikan atau diolah atau diinterpretasikan untuk digunakan dalam proses pengambilan keputusan ${ }^{[4]}$.

E-learning terdiri dari dua bagian, yaitu "e" yang merupakan singkatan dari 'electronic' dan 'learning' yang berarti 'pembelajaran', Jadi e-learning berarti pembelajaran dengan menggunakan jasa/bantuan perangkat elektronika, khususnya perangkat komputer. Karena itu, e-learning sering disebut pula online course. Dalam berbagai literatur, e-learning didefinisikan sebagai berikut:

"e-Learning is a generic term for all technology supported learning using an array of teaching and learning tools as phone bridging, audio and videotapes, teleconferencing, satellite transmissions, and the more recognized webbased training or computer aided instruction also commonly referred to as online courses." [1].

E-learning dalam berbagai karakteristik, antara lain: (1) e-learning merupakan penyampaian informasi, komunikasi, pendidikan, pelatihan secara online; (2) elearning menyediakan seperangkat alat yang dapat memperkaya hasil-hasil belajar yang diperoleh hanya secara konvensional, sehingga dapat menjawab tantangan perkembangan globalisasi; (3) e-learning tidak berarti menggantikan model belajar konvensional di dalam kelas, tetapi memperkuat model belajar konvensional melalui pengayaan konten dan pengembangan teknologi pendidikan; (4) elearning akan menyebabkan kapasitas peserta didik bervariasi bergantung pada bentuk konten dan alat penyampaiannya. Makin baik keselarasan antara konten dan alat penyampaian dengan gaya belajar peserta didik, maka akan lebih baik kapasitas peserta didik yang pada gilirannya akan memberikan hasil yang lebih baik.

\section{ANALISA DAN PEMBAHASAN}

Sistem yang ada saat ini, maka waktu berkomunikasi antara guru dengan siswa sangat singkat sehingga kemungkinan besar 
ISSN : 2548-6985

setiap materi yang di ajarkan oleh guru tidak dapat sepenuhnya diserap atau dipahami oleh siswa. Adapun gambaran dari sistem yang sedang berjalan saat ini di SMK Swasta Pencawan Medan Program Studi Multimedia dapat dilihat seperti pada Gambar 1.

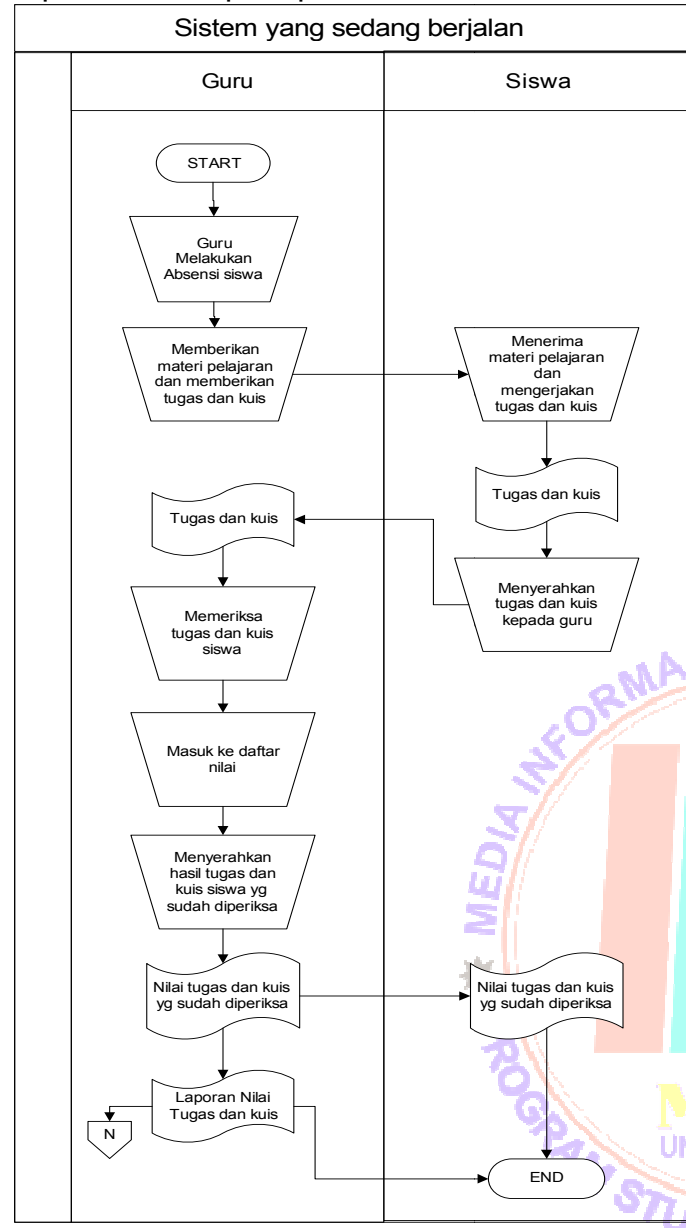

Gambar 1. Diagram Alir Sistem Yang Sedang Berjalan

Adapun sistem yang diusulkan adalah dengan membangun sebuah sistem yang berbasis web, dimana pada sistem yang dibangun setiap guru dan siswa dapat berinteraksi dimanapun berada yaitu dengan menerapkan E-Learning Berbasis Web pada SMK Pencawan Medan. Adapun gambaran dari sistem yang dibangun dapat dilihat seperti pada Gambar 2.

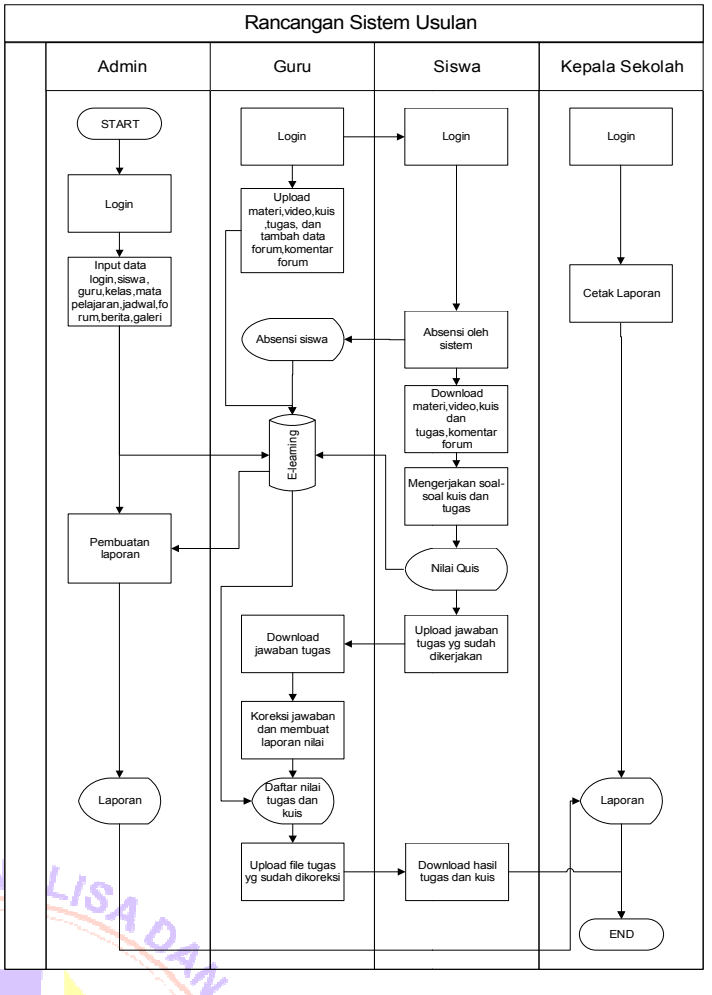

Gambar 2. Diagram Alir Sistem Yang Di Usulkan

\section{HASIL DAN IMPLEMENTASI}

1. Halaman Pengunjung Umum

Halaman utama pengunjungmerupakan tampilan utama pada saat sistem dijalankan, dimana pada menu utama terdapat berbagai info tentang sekolah dan link-link yang berfungsi untuk berpindah dari satu halaman ke halaman lainnya. Bentuk menu utama dapat dilihat pada Gambar 3.

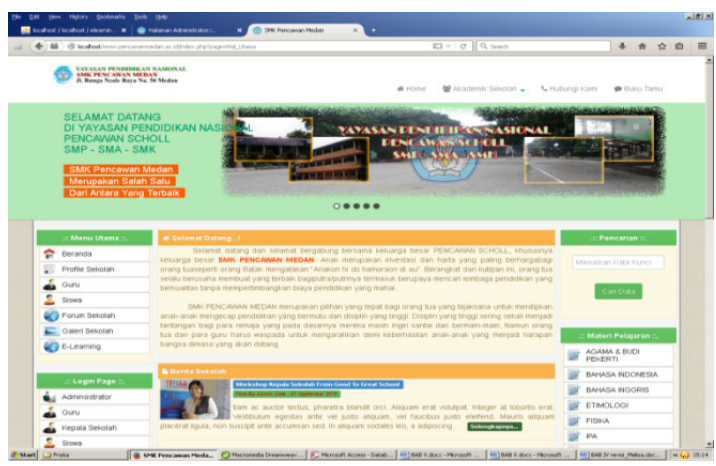

Gambar 3. Halaman Utama Pengunjung Umum 
ISSN : 2548-6985

\section{Halaman Siswa}

Halaman siswa berfungsi untuk menampilkan informasi siswa yang terdaftar di SMK Pencawan Medan untuk jurusan multimedia dan setiap siswa dikelompokkan berdasarkan kelas. Gambar 4 merupakan tampilan halaman siswa.

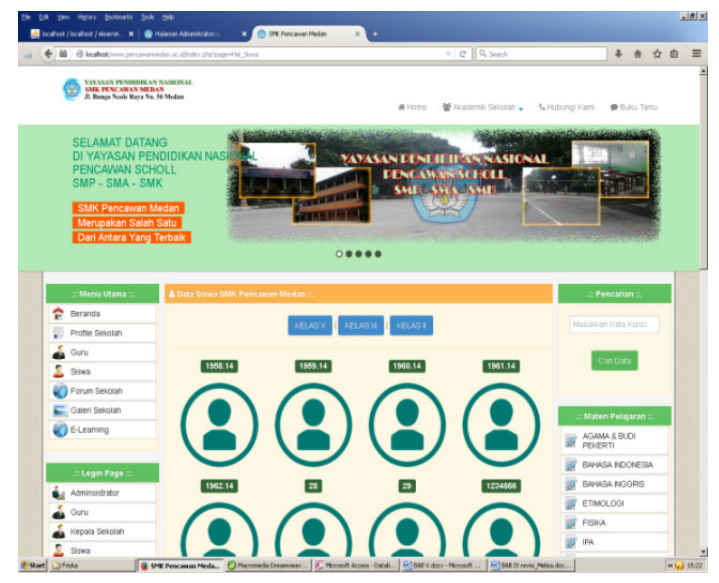

Gambar 4. Halaman Siswa

\section{Halaman Jadual E-learning}

Halaman E-Learning sekolah berfungsi untuk menampilkan informasi kelas E-Learning pada SMK Pencawan Medan untuk jurusan multimedia. Dimana kelas E-Learning bisa diikuti jika siswa atau guru sudah melakukan login. Bentuk halaman E-Learning sekolah dapat dilihat pada Gambar 5.

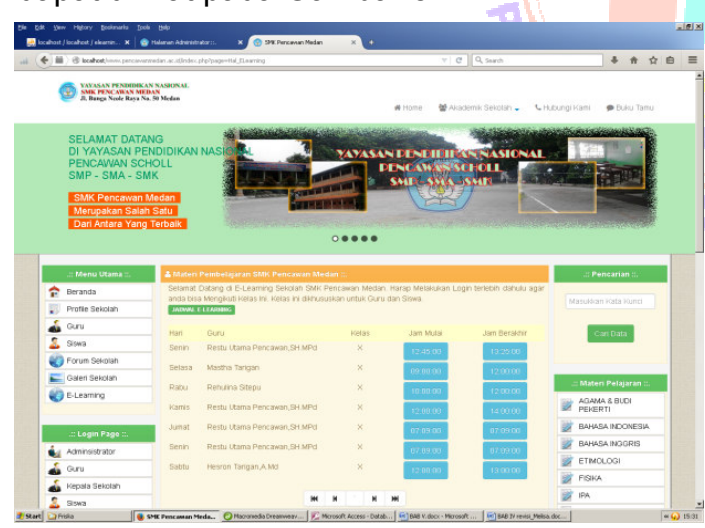

Gambar 5. Halaman Jadual E-Learning

\section{Halaman Utama Administrator}

Halaman utama administrator merupakan tampilan awal yang akan ditemui seorang administrator setelah berhasil melakukan login. Pada halaman utama administrator terdapat beberapa menu yang dapat digunakan untuk mengolah data dalam sistem E-Learning. Bentuk halaman utama administrator dapat dilihat pada Gambar 6 .

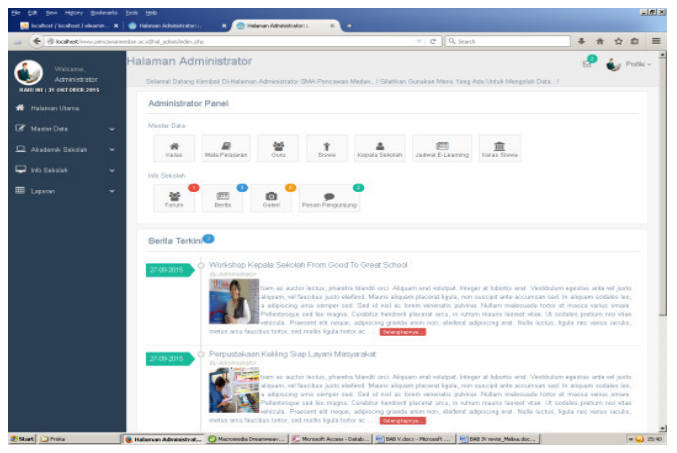

Gambar 6. Halaman Utama Administrator

\section{Halaman Kelas Siswa}

Halaman kelas siswa berfungsi untuk memproses kenaikan kelas siswa pada SMK Pencawan Medan. Bentuk halaman kelas siswa dapat dilihat seperti pada Gambar 7.

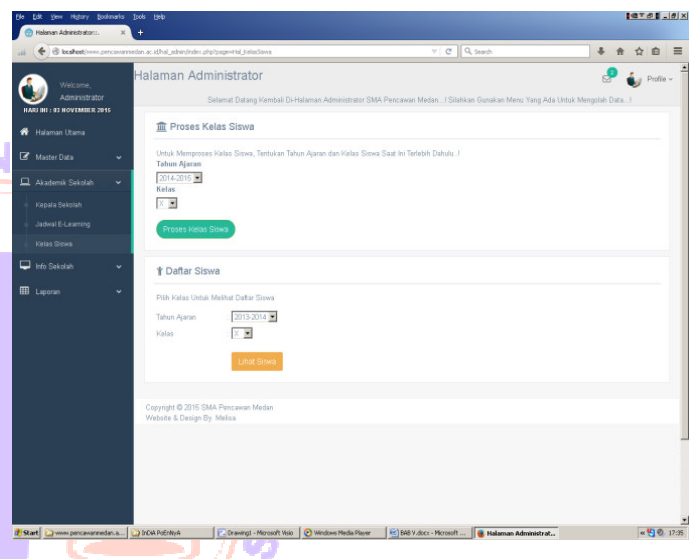

Gambar 7. Halaman Kelas Siswa

\section{KESIMPULAN}

Berdasarkan hasil pembahasan maka dapat diambil kesimpulan sebagai berikut:

1. Aplikasi e-learning pada SMK Swasta Pencawan Medan berguna bagi guru dalam memberikan materi pelajaran yang diberikan di kelas secara online. Sehingga materi masih dapat tersampaikan meski guru berhalangan hadir. Sebaliknya, siswa tetap bisa mendapatkan materi yang diajarkan oleh guru meski tidak hadir di kelas.

2. Aplikasi e-learning pada SMK Swasta Pencawan Medan terdapat fasilitas forum yang berguna sebagai wadah untuk melakukan tanya jawab, berpendapat serta berdiskusi sehingga memungkinkan interaksi antara siswa dan guru maupun antar siswa itu sendiri di luar kelas tanpa harus bertemu langsung.

3. Aplikasi e-learning pada SMK Swasta Pencawan Medan dapat menjadi wadah untuk menampung informasi yang 
diberikan sekolah secara efisien dengan memanfaatkan perangkat komputer dan akses internet yang mampu menjangkau penyebaran informasi secara luas, tepat dan cepat.

Aplikasi e-learning pada SMK Swasta Pencawan Medan masih dapat dikembangkan lagi. Dibawah ini adalah beberapa saran untuk pengembangan aplikasi e-learning SMK Swasta Pencawan Medan, yaitu:

1. Aplikasi e-learning ini masih dapat ditambahkan dengan fitur-fitur multimedia yang berhubungan dengan kebutuhan pembelajaran dan sekolah.

2. Aplikasi e-learning ini perlu disesuaikan dengan kurikulum pembelajaran yang selalu berubah-ubah. Seperti dalam hal pemberian materi pembelajaran.

\section{DAFTAR PUSTAKA}

1. Darmawan, Deni. Pengembangan ELearning Teori dan Desain. Bandung:Rosdakarya, 2014.

2. Fathansyah. Basis data. Bandung Informatika, 2012.

3. Jogiyanto. Analisa Dan Disain Sistem Informasi Pendekatan Terstruktur. Yogyakarta:ANDI, 1993.

4. Kadir, Abdul. Pengenalan Sistem Informasi. Yogyakarta:ANDI, 2014.

5. Rahman, Dedy. Perancangan Basisdata Relasional. Bandung:Politeknik Telkom , 2009.

6. Raharjo, Budi (dkk). Modul Pemrograman Web. Bandung:Modula, 2012.

7. Sidik, Betha. Pemrograman Web Dengan PHP. Bandung:Informatika, 2006.

8. Sommerville, lan. Software Engineering. Jakarta:Erlangga, 2003. 